\title{
The Phenomenological Life-World Analysis and the Methodology of the Social Sciences
}

\author{
Thomas S. Eberle
}

Published online: 23 November 2010

(C) Springer Science+Business Media B.V. 2010

\begin{abstract}
This Alfred Schutz Memorial Lecture discusses the relationship between the phenomenological life-world analysis and the methodology of the social sciences, which was the central motive of Schutz's work. I have set two major goals in this lecture. The first is to scrutinize the postulate of adequacy, as this postulate is the most crucial of Schutz's methodological postulates. Max Weber devised the postulate 'adequacy of meaning' in analogy to the postulate of 'causal adequacy' (a concept used in jurisprudence) and regarded both as complementary and, in the context of sociological analysis, critical. Schutz extracted the two postulates from the Neokantian epistemology, dismissed the concept of causality, and reduced Weber's two postulates of adequacy into one, namely, the adequacy of meaning. I discuss the benefits and shortcomings of this reduction. A major problem, in my view, is that Schutz's reformulation lost the empirical concern that was inherent in Weber's 'causal adequacy'. As a result, the models of economics (which shaped Schutz's conception of social science) are considered to be adequate if they are 'understandable' to an everyday actor, even when they are based on the most unrealistic assumptions. To recapture Weber's empirical orientation I recommend a more restrictive interpretation of the postulate of adequacy that links it to qualitative research and unfolds the critical potential of Schutz's phenomenological life-world analysis. My second goal is to report on some current developments in German sociology in which a number of approaches explicitly refer to Schutz's analysis of the life-world and attempt to pursue 'adequate' empirical research. This lecture focuses on three approaches: ethnophenomenology, life-world analytic ethnography, and social scientific hermeneutics.
\end{abstract}

This paper was presented as the Alfred Schutz Memorial Lecture at the meetings of the Society for Phenomenology and the Human Sciences in Arlington, VA, October 30, 2009. The Lecture was co-sponsored with the Center for Advanced Research in Phenomenology.

T. S. Eberle (ه)

Department of Sociology, University of St. Gallen, St. Gallen, Switzerland e-mail:Thomas.Eberle@unisg.ch 
Keywords Alfred Schutz · Phenomenology - Life-world analysis · Methodology · Adequacy · Qualitative research · Ethnophenomenology · Social science

Thank you very much for this honorable invitation to give the Alfred Schutz Memorial Lecture this year in commemoration of the 50th anniversary of Schutz's early death. The work of Alfred Schutz's changed my life and I was in a continuous dialogue with him most of my life. I have published two books (Eberle 1984, 2000) and many essays on Alfred Schutz in German, in particular in regard to phenomenology and the methodology of the human sciences and I have co-edited the volume with his methodological writings in the new German complete edition of Alfred Schutz's works (Schutz 2010).

I guess many of us would be more than happy if our own work was still published and discussed in as lively a manner as his, 50 years after our death.

Alfred Schutz's work is multilayered and can thus be viewed from a variety of perspectives. His central motive, however, was without a doubt the contribution of life-world analysis to the methodology of the social sciences. It was the declared goal of his major work The phenomenology of the social world to develop a "philosophically founded theory of method" for social science research (Schutz 1967: xxxi). Despite the numerous topical ramifications of his work, Schutz never lost sight of this goal. Accordingly, his draft of the structure for the planned opus "The Structures of the Life-World" features a chapter titled "Sciences of the LifeWorld" (Schutz and Luckmann 1973: xvi) as the crowning conclusion. ${ }^{1}$ In this concluding work, the diverse facets of the phenomenological analysis of the lifeworld were therefore arranged to culminate in a philosophical grounding of the sciences of the life-world. Since Luckmann decided to cut this chapter without substitution when editing the Structures posthumously, some scholars have lost sight of this basic intention. Therefore, this memorial lecture intends to discuss the interrelation between phenomenological life-world analysis and the methodology of the social sciences. Of course, the topic is much too broad for a single lecture and has to be focused.

I will pursue two major goals. First, I will concentrate on the methodological postulate of adequacy, exploring how Max Weber devised it, what Alfred Schutz made of it and how it could in my view be interpreted in a much more radical way and made much more relevant for modern qualitative research.

Secondly, I assume that you are expecting from a European scholar to learn about the current developments in Europe. As I am a German Swiss, I will report on some developments in German Europe-which comprises Germany, Austria and parts of Switzerland-developments which are not well known over here as only very few publications were translated into other languages so far.

\footnotetext{
${ }^{1}$ In the quoted English edition it says "sciences in the life-world" but this is a mistake. In Schutz's German notebooks it is clearly written "sciences of the life-world", which was translated correctly in the appendix of the second volume of the Structures (Schutz and Luckmann 1989: chapter 6, pp. 177).
} 


\section{The Life-World as a Foundation of the Social Sciences}

The Phenomenology of the Social World is - in my view-the key work of Alfred Schutz. It lays the foundation to all further streams of reflection in his later works. Compared to the analytical depth and systematic approach of the analyses found here, some of his later examinations seem much less elaborated-especially his methodological considerations. On the other hand, he expanded the spectrum of his analysis with important additions, particularly through his contributions on the lifeworld as the unquestioned ground of science (subsequent to the Crisis-book by Husserl [1936] 1970), on multiple realities (referring to William James 1907), on the systems of relevance as well as through the distinction between the everyday world and the world of science and the elaboration of their interrelation, in terms of different levels of construction and different rationalities. Because of this, two and a half decades later a more differentiated view on the methodology of the social sciences had emerged. According to the outline of chapters for The Structures of the Life-World preserved in his index cards, Schutz planned a chapter on the Sciences of the Life-World as the culmination or conclusion of his analyses.

Luckmann, however, refrained from publishing this final chapter. He stated two main reasons for this: firstly, Schutz's drafts did not seem to add anything to his paper "Common-Sense and Scientific Interpretation of Human Action" (Schutz 1962), which constitutes the most substantial methodological contribution after The Phenomenology of the Social World. Secondly, Luckmann made clear that his own convictions differed from those of Alfred Schutz and that due to the lack of directions, he could not have written this chapter true to Schutz's intent (Luckmann 1974: xvii). Both reasons are comprehensible, but it had the effect that the immanent interrelation of Schutz's analysis of the life-world and the methodology of the social sciences is completely absent in the Structures of the Life-Worldwhich should have represented the summary volume of his work.

The fact that the social world is always meaningfully pre-interpreted and that this constitutes a difference between the natural and the social sciences, usually finds a consensus nowadays. Which consequences are to be drawn from this, remains, however, disputed. Which consequences has Schutz drawn?

Schutz maintains that the distinctive feature of the social sciences lies in their understanding of the world of contemporaries. This follows from the distinct attitude of the scientist as an "uninterested observer", whose interpretation of meaning is not bound to pragmatic motives but who is striving for truth. The boundaries of this quest are set on the one hand by the scientific system of relevance, especially by the present problem, and on the other hand by the corpus of knowledge of the respective discipline. Schutz subsumes the principles by which theoretical models should be construed under the following methodological postulates (Schutz 1962a, b, 1964a, b):

(1) The principle of relevance: as already mentioned.

(2) The postulate of logical consistency: which is undisputed.

(3) The postulate of subjective interpretation: which means that explanations in the social sciences have to refer ultimately to the subjective meaning of action. 
(4) The postulate of adequacy: which means that the constructs of the social scientist have to be consistent with the common-sense constructs of actors.

(5) In addition, he sometimes invokes the postulate of rationality: which means that models of rational actions are preferred since they are especially evident and form a point of reference for the characterization of deviant types. This postulate is not mandatory, although economics especially continues to adhere to it. (And it may be added that Schutz says in his correspondence to Adolphe Löwe, that Pareto was right when he said that rational actions constitute the realm of economics and irrational actions the realm of sociology (Schutz 1955a).)

\section{The Postulate of Adequacy}

In my view, the postulate of adequacy is crucial, and I would like to discuss it here. When are scientific constructs adequate?

\section{Adequacy in Max Weber's Work}

Let us briefly recapitulate Max Weber, from whom Schutz draws in this matter: explanatory understanding in Weber's sense, which captures the actual as well as the motivational meaning, has to conform to two kinds of adequacy: to adequacy of meaning and to causal adequacy:

We apply the term 'adequacy of meaning' to the subjective interpretation of a coherent course of conduct when and insofar as, according to our habitual modes of thought and feeling, its component parts taken in their mutual relation are recognised to constitute a 'typical' complex of meaning. It is more common to say 'correct.' The interpretation of a sequence of events will on the other hand be called causally adequate insofar as, according to established generalisations from experience, there is a probability that it will always actually occur in the same way. ... Thus causal explanation depends on being able to determine that there is a probability, which in the rare ideal case can be numerically stated, but is always in some sense calculable, that a given observable event will be followed or accompanied by another event. (Weber [1922] 1978: 11 —emphasis added by T.S.E.) ${ }^{2}$

In other words, adequacy of meaning is only reached if explanatory understanding is evident. But even an evident interpretation remains only a hypothesis as long as the criterion of causal adequacy is not fulfilled as well. Conversely, a statement that is causally adequate remains only a non-understandable statistical probability as long as the criterion of adequacy of meaning has not been fulfilled (Weber [1922]

\footnotetext{
${ }^{2}$ This excerpt follows the translation by G. Roth and C. Wittich (Weber [1922] 1978), except for the first phrase (until "insofar as"), where the translation by W. Heydebrand (in Weber 1994) was chosen as it seems to be closer to the original meaning. (The first chapter of Wirtschaft und Gesellschaft was also published as a separate article in the Gesammelte Aufsätze zur Wissenschaftslehre and was thus later translated twice.)
} 
1978). In Weber's words: "Statistical uniformities constitute understandable types of action ..., and thus constitute 'sociological generalisations' only when they can be regarded as manifestations of the understandable subjective meaning of a course of social action." Such generalizations always exhibit a "correspondence between the theoretical interpretation of motivation and its empirical verification" (Weber [1922] 1978: 11).

Weber tried to build a bridge here between the theory of objective probability as the physiological psychologist Johannes von Kries had developed, and the interpretive tradition since Dilthey. Von Kries saw that general causal relationships between actions and results are relevant for penologic attributions, as an action must be suited to promote a certain result according to common (statistical) experience. Only if this is the case, an "adequate causation" can be stated. For example: if a coachman falls asleep and his horses take the wrong road at an intersection, and his passenger is subsequently killed by lightning, there is no adequate causation between falling asleep and the death of the passenger, "since the sleeping of coachmen in general does not heighten the possibility of being killed by a lightning, (that is) it is generally not capable of inducing it" (von Kries 1889: 532-transl. T.S.E.).

Von Kries referred to jurisprudence, where causal adequacy has been an ongoing issue until today. Weber saw analogical issues in history and sociology. Scientific analysis has to rely on "nomological knowledge" which is composed of "certain known empirical rules, particularly those relating to the ways in which human beings are prone to react under given situations" (Weber 1949: 174). Since human beings tend to react differently each time and therefore divert from "empirical rules", only probabilistic statements can be made about their actions. For this reason Weber takes up von Kries's notion of "adequate causation": In relation to human action, the opposite of "coincidence" cannot be "necessity", but only "adequacy". Therefore, the construction of a causal relationship refers to the relative frequency of occurrence of a type of action, in other words: to its objective likelihood. If such an interrelation cannot be "adequately" established, one needs to speak of "coincidental" causation (Weber 1949: 185).

Weber coined the term "adequacy of meaning" in analogy to the notion of causal adequacy, and he suggests assessing the degree of adequacy of meaning "according to our habitual modes of thought and feeling" (Weber 1994: 7). In the neo-Kantian framework of Rickert's work, an interpretive sociology had to deliver explanations which fulfilled both types of adequacy: causal adequacy as well as adequacy of meaning.

\section{Schutz's Dismissal of Causal Adequacy}

As is generally known, Schutz dismissed the notion of causal adequacy. Already in his early notes written in Vienna which have been recently published in German (Schutz 2007), one can read:

(...) the social sciences have to reject the question of causality within the interrelations of their objects as inadequate and refer it to the realm of mechanistic world explanations, which will indeed (what can be shown 
a-priori) never be able to solve a single social-scientific problem, be it with the help of neurosciences, theories of psychophysical parallelisms or any similar theories. (Schutz 2007: 227—transl. by T.S.E.)

What Weber means by the postulate of causal adequacy, says Schutz in The Phenomenology of the Social World, is nothing else than "the postulate of the coherence of experience" (Schutz 1967: 232): For every typical construct there must exist a chance that "according to the rules of experience an act will be performed in a manner corresponding to the construct" (Schutz 1967: 232). If causal adequacy means that the typical construct of a human act has to be consistent with the entirety of our experience and if every experience of human action implies its embeddedness in a meaning-context, "all causal adequacy which pertains to human action is based on principles of meaning-adequacy of some kind or other" (Schutz 1967: 233). For Schutz, causal adequacy is only a special case of meaning-adequacy. Subsequently, Schutz integrated both postulates into the postulate of adequacy.

This move had two major implications:

First, in contrast to Weber, Schutz abandons talk of causality completely, be it causal adequacy in von Kries's sense on the level of objective probabilities, or be it on the level of subjective probabilities. Crucial for Schutz are the in-order-tomotives, which may be linked to because-motives but not in a causal sense. In The Phenomenology of the Social World he is also quite explicit that causality in the social sciences can be substituted by rationality-in accordance with the rational choice theories developed in economics. I will come back to this.

The second-and more important - implication is, that Schutz dropped the requirement of empirical verification from the postulate of adequacy, while it was an integral part of Weber's concept. Let me repeat Weber's quotation: Sociological generalizations always exhibit a "correspondence between the theoretical interpretation of motivation and its empirical verification” (Weber 1994: 6).

By contrast, Schutz restricts the postulate of adequacy more and more to adequacy of meaning in a narrow sense. In 1943, in conjunction with the remarks in The Phenomenology of the Social World, he still wrote:

The postulate of adequacy requires that the typical construction be compatible with the totality of both our daily life and our scientific experience. (Schutz 1964b: 88)

But it is exactly this aspect that he drops later on. The final version of the postulate of adequacy, as found in "Common-sense and scientific interpretation of human action” reads:

Each term in a scientific model of human action must be constructed in such a way that a human act performed within the life-world by an individual actor in the way indicated by the typical construct would be understandable for the actor himself as well as for his fellow-men in terms of common-sense interpretation of daily life. Compliance with this postulate warrants the consistency of the constructs of the social scientist with the constructs of common-sense experience of the social reality (Schutz 1962a: 44-emphasis by T.S.E.; analogous to Schutz 1962b: 64, 1964a: 65). 
The subjunctive makes us hesitate: Obviously, only the consistency between scientific and common-sense constructs is addressed, while causal adequacy, that is, the conformity with experience, has been dropped from the postulate. In this version, the criterion of adequacy is already fulfilled if an action that coincides with the scientific construct would be understandable in the course of common-sense thinking - obviously it is no longer important whether this action does in fact occur empirically or whether it remains a sheer model.

Schutz reduced the postulate of adequacy to the aspect of meaning-adequacy. At the same time, he does not tie it to his postulate of the coherence of experience, which he said was the substitute for Weber's causal adequacy. This shift of focus compared to the adequacy concept of Weber can in my view be traced back to his specific view of science which was profoundly influenced by his colleagues from the Mises circle who where mainly economists. Ludwig Mises, a prominent member of the second generation of the Austrian School of economics, advanced a view of economics which consisted of a-priori statements. He drew a sharp distinction between theoretical economics which were aprioristic, and economic history which dealt with empirical data. Max Weber endorsed the Austrian concept of theoretical economics - in opposition to the Historical Economic School around Gustav Schmoller in Germany-but criticized the naturalistic self-misunderstanding of aprioristic theory. In fact, he contended, they are working with ideal types. Mises reproached Weber's misunderstanding of what aprioristic science means, and went on to develop a praxeology, an aprioristic theory of human action (published in 1940 in German, shortly before his emigration to the United States, and published in English in 1949 in a reworked edition). Schutz was caught in the middle and undertook a careful attempt to reconcile the two: Mises was right, he argued, that on a very abstract level his concepts and propositions were aprioristic, but as soon as they are related to concrete data they would inevitably become ideal types (Schutz 1967).

However, Schutz hardly ever came into contact with empirical research. His knowledge of social science was above all influenced by his friends from the MisesCircle, in other words, from Austrian Economics (cf. Prendergast 1986). The impressive work of Fritz Machlup, with whom Schutz maintained close contact, consists as well mainly of those typical non-empirical economic models which are based on relatively simple assumptions in order to keep the theoretical complexity manageable (see Machlup 1978). If Schutz describes scientific constructs as constructs of homunculi and ties the postulates of logical consistency, subjective interpretation and adequacy to them (Schutz 1962a: 43), then even economic models most aloof from empirical data seem to match these principles. Schutz's methodological postulates read like descriptions of the prevalent self-conception of the economics of that time (see Eberle 1988).

It shall be added at this point that the famous economist Milton Friedman from the University of Chicago, published the so-called Friedman-theorem in 1953 which found wide appeal among economists:

Truly important and significant hypotheses will be found to have 'assumptions' that are wildly inaccurate descriptive representations of reality, and, in general, the more significant the theory, the more unrealistic the assumptions (in this sense). (Friedmann 1953: 14) 
For Friedman, unrealistic assumptions of a theoretical model are not a problem at all - the only thing that counts is the success of the prognoses derived from it. But can a model that is based on unrealistic assumptions comply with the methodological postulate of adequacy? Interestingly enough, Machlup completely takes sides with Friedman on this matter by claiming with regard to another great American economist, Samuel Samuelson, that he wrote his best works whenever he made unrealistic assumptions (Machlup 1964: 753). Machlup, however, holds the Friedman-theorem to be in need of additions: the assumptions would not need to be realistic, but adequate (Machlup 1954: 17). Needless to say, if mental images that are based on unrealistic assumptions are supposed to comply with the postulate of adequacy, it obviously must be broadly defined. Machlup defines it-with reference to Schutz-in the following way:

The fundamental assumptions of economic theory are not subject to a requirement of independent empirical verification, but instead to a requirement of understandability in the sense in which man can understand the actions of fellowmen. (Machlup 1954: 17)

Schutz's self-conception as a methodologist has always been characterized by modesty: "Methodology is not the preceptor or the tutor of the scientist. It is always his pupil ..." (Schutz 1964b: 88). His conception of science was deeply influenced by the "method of mental images" (Mises 1949: 227ff.) of the Austrian School of economics. This holds also true in regard to the conceptualization of rationality, in which he, however, takes sides with Weber against Mises. But the postulate of rationality that social-scientific models have to comply with is formulated subjunctively:

The rational course-of-action and personal types have to be constructed in such a way that an actor in the life-world would perform the typified action if he had a perfectly clear and distinct knowledge of all the elements, and only of the elements, assumed by the social scientist as being relevant to his action and the constant tendency to use the most appropriate means assumed to be at his disposal for achieving the ends defined my the construct itself. (Schutz 1962a: 45-emphasis by T.S.E.)

Again, the subjunctive indicates that the scientific models form an (objective) possibility from which acts in the everyday world deviate more or less strongly. Earlier, Schutz had extensively elaborated the "paradox of rationality on the level of common-sense action" which is to be found in the fact that

... the more standardized the pattern is, the less the underlying elements become analyzable for common-sense thought in terms of rational insight.... Only on the level of models of interaction patterns constructed by the social scientist in accordance with certain particular requirements defined by the methods of his science does the concept of rationality obtain its full significance (Schutz 1962a: 33).

The postulate of rationality formulated in the subjunctive, however, can again be fulfilled by all economic models, as long as they are just based on the homo 
economicus - even if their assumptions are completely unrealistic. Schutz obviously employs his analyses of the life-world primarily in order to explicate the differences in orientation between homunculi-constructs and actors guided by common senseand therefore the inevitable distance between a scientific model and social reality as it is experienced in the life-world.

\section{A More Radical Interpretation of the Postulate of Adequacy}

Before I became a sociologist and a phenomenologist I was trained as an economist. It is probably due to this background, that I see much critical potential in Schutz's phenomenological life-world analysis. Many economists still uphold the selfdescription that their discipline is the queen of the social sciences-a designation which Auguste Comte once reserved for sociology. At the same time, economics usually applies rather simple explanatory models of human behavior. If you would have such homunculi in an organization as Economic Men, you would never see a collaboration happen. Many economists went so far as to abolish the phenomenon of altruistic motives, by reinterpreting them into factually egoistic motives: altruists, too, are actually egoists, they just maximize their personal benefit by helping others. By this procedure, the universe of meanings of the social world is dramatically reduced. This is the so-called KISS-procedure, keep the model simple and stupid, so you can handle it well. Although this is said to be a methodological procedure, it finally results in a kind of simple ontology as well.

I would like to recommend therefore that we apply a more restrictive interpretation of Schutz's postulate of adequacy: The postulate of adequacy means that the constructs of the social scientist describe and explain a concrete course of action empirically appropriately in the actor's perspective.

Schutz's detailed analysis of the lifeworld would not make much sense if we did not require the social sciences to refer to the actor's actual orientation in everyday life. And it is not just intelligibility of the scientific constructs which is requiredeconomic models of man are usually highly intelligible in a common-sense perspective-it is their empirical appropriateness which is essential. And it is not just the common-sense constructs that must be referred to by a scientist, but the actual orientation of actors in their actions and interactions. As Garfinkel (1967) has shown, common-sense constructs are often just glosses which are not precise enough to grasp the actors' orientations.

If we employ a concept of adequacy which explicitly refers to life-world analysis and implies empirical "verification" in Weber's sense, we can reject many simplistic economic explanations as being “inadequate”. Is this in Schutz's sense?

In The Phenomenology of the Social World, Schutz calls the pure economics of Mises a "perfect example of an objective meaning-complex about subjective meaning-complexes" (1967: 245), and the law of marginal utility is interpreted as "a stipulation that merely marks out the fixed boundaries of the only area within which economic acts can by definition take place" (1967: 245). Unlike Kaufmann, whom he invokes, Schutz decouples this economic principle from the economic context and generalizes it formally. This, as I have outlined before, was a heroic attempt to reconcile Weber and Mises. However, formulated in this generalized 
way, the economic principle can be applied to almost anything: Not only to decisions of consumer or business persons, but also to lovers and their relationships, to employees in an organization, to the behavior of family members, and so onGary Becker (1991) won the Nobel-prize for his "Treatise on the Family" for analyses of this sort.

The fact that Schutz as a methodologist never elevated himself to be a teacher or tutor of the economists but instead remained their scholar, could explain his reluctant formulation of the postulate of adequacy. However, he was much more critical in his personal correspondence than in his publications. In a letter to Adolphe Löwe, he criticized his teacher Ludwig Mises in no less than three different respects.

(1) the decisive problem involved (in the process of choosing) is taken just for granted by Mises, that is the problem how it comes that things stand to choice at all (Schutz 1955b: 5-6);

(2) He overlooks also the difference which seems to be vital for me, namely on the one hand choosing between objects equally within my reach and, on the other hand, choosing between projects of actions which have to be carried out by me (Schutz 1955b: 6);

(3) Mises is trying to develop a general praxeology which he identifieserroneously, as I think-with the theory of economic action, namely an action according to the assumed scale of preferences of the actor. ... If this were the case there would be no human action whatsoever which were not an economic action (Schutz 1955b: 3). And if gentlemen prefer blondes, they are economic subjects.

The first two arguments point to the process of choosing in the subjective consciousness and the third to the criteria which define the realm and subject matter of economics. So what did Schutz do about it?

Schutz dealt with both problems in a longer manuscript in the middle of the 1940s. In the first part, he examined the act of choosing in everyday situations, and in the second he traces its conception in a scientific model and illustrates this with the example of theoretical economics. After having been caught between two stools with this attempt, "the philosophical part being of no interest to economists and the economic part of no interest to philosophers" (Schutz 1955a: 1), he finally published the first part separately in a phenomenological-philosophical journal in 1951 (Schutz 1962c) and held back the second part until the end of his life (it was published posthumously by Lester Embree: Schutz 1972).

With his analysis of the acts of choosing in the life-world, Schutz hoped to show that the utilitarian modeling of acts of choosing is inadequate and that Mises's praxeological model is in need of elaboration in several critical aspects (see Eberle 2009). A phenomenological description of the process of choosing must not be based on reconstructions of past experiences, but has to start right from amidst the stream of consciousness. This prerequisite has been fulfilled by the works of Husserl, Bergson, and Leibniz, whose findings Schutz combines for this reason. From Husserl, he takes the constitution of problematic options as the precondition to every possible choice, from Bergson the time perspectives implicated in the process 
of choosing, and from Leibniz the concurrence of volitive intentions which leads to the final 'fiat' of the decision. On this basis it becomes immediately clear that the utilitarian model of choosing and decision making is just an interpretation scheme for explaining because-motives of actions already foregone and is missing the polythetic course of choosing (Schutz 1972: 573f.).

These statements by Schutz provide sufficient evidence to me to suggest that Schutz's understanding of adequacy was actually more restrictive than his definitions make visible. Indeed, his lifelong effort to achieve a theory of the meaning constitution of the social world would not have made much sense if he had not aimed at contributing towards a more adequate methodology of social scientific research. Many interpreters of Schutz have overlooked the radical difference between ideal types in Schutz's and Weber's sense. Whenever the two are confused, a fundamental misinterpretation may result. Ideal types in Weber's sense are constructions within a neo-Kantian framework, ideal types in Schutz's sense are constructions within a phenomenological framework. Kantianism was concerned with formal aprioris, phenomenology with material aprioris. For neo-Kantianism the (scientific) method is crucial, for phenomenology the experience is crucial. The construction of an ideal type in Weber's sense is based on methodical decisions by the scientist only. Scientific constructions in Schutz's sense, however, must relate to the concrete experiences of actors in their everyday world. This does not mean that scientific ideal types must relate to the actors' common-sense typifications, but, as has been demonstrated above with the example of the act of choosing, that scientific constructions must relate to how actors actually make sense in their everyday life. Schutz's analysis of meaning constitution in the social world provides the link between the constructions of the first and second order. Whenever Schutz's approach is equated with Weber's methodology, the crucial point is missed (cf. Eberle and Srubar 2010).

Schutz's life-world analysis also provides the means to make sense of his methodological postulates. As I have argued, this results in a radicalized interpretation of the postulate of adequacy. In this vein, scientific constructions can only be accepted as adequate,

if they are on the one hand designed according to the processes of meaning constitution in daily life and if on the other hand they grasp the actual orientation of actors in concrete situations empirically correctly. In this form, the postulate of adequacy would be suited to function as a quality criterion of qualitative social research and to constructively replace the usual suspects like objectivity, validity or reliability which originated in the context of quantitative research.

\section{Phenomenology and Sociology in the German Context}

Schutz tied his analysis of the life-world closely to Weber's theory of action, and his methodological arguments are oriented to Weber's Outline of interpretive sociology (Weber [1922] 1978) as well as to the Austrian School of Economics. This happened for biographical reasons, not out of necessity. The structures of the lifeworld are not just compatible with a certain kind of sociology. Firstly, as a protosociology they form a framework in which in principle any kind of social science 
can be located. Secondly, as Garfinkel $(2002,2006)$ has shown with ethnomethodology, the analysis of the life-world can also be redrafted completely. Since the processes of the constitution of meaning form the core of the analysis of the lifeworld, they are, however, only compatible with an interpretive sociology and a hermeneutic approach to the social world. By now, a number of approaches of social-scientific hermeneutics have been developed, among which several explicitly refer to Schutz's analysis of the life-world, if in different ways.

As promised, I am going now to report on some developments in the German part of Europe.

First of all-and this may surprise many of you-there is no such thing as a "Phenomenological Sociology".3 The reason is that Thomas Luckmann (1983) sharply distinguished the two: either you do phenomenology or you do sociology. Phenomenology is a philosophy, its method proceeds egologically and it analyzes phenomena of subjective consciousness. Sociology is a science, its method proceeds cosmologically and it analyzes phenomena of the social world. The phenomenological lifeworld analysis delivers a protosociology and provides a mathesis universalis, a formal framework for any kind of social scientific endeavour. I don't know if you have noticed, but The Social Construction of Reality of Berger and Luckmann (1966) is built on the same distinction: The first part about the analyses of Schutz is called 'pre-sociological', and then follow the two sociological parts, society as an objective reality and society as a subjective reality.

As all German speaking sociologists with a phenomenological, notably Schutzian background were directly or indirectly trained by Luckmann, most of them adhere to this distinction between phenomenology and sociology, and many take Berger and Luckmann (1966) as their theoretical orientation. In the last 15 years, most phenomenologically oriented sociologists who do empirical research, used ethnography as a multiple-method procedure to analyze different sorts of data. The formal structures of the life-world are considered as anthropological givens and as universal, and all phenomena which are historically or culturally variable are considered as objects not of phenomenological but of sociological research.

How rich and well-differentiated the empirical research building on Schutz's analysis of the life-world presents itself today is shown impressively by two recent volumes, one on The Untranslatability of Cultural Differences, edited by Jochen Dreher and Peter Stegmaier (2007), and another one on Phenomenology and Sociology, edited by Jürgen Raab et al. (2008). On the one hand, they mark the enormous difference between today's social-scientific research and the role models that Schutz oriented to. On the other hand, they both mirror the variety of empirical approaches to the social world that strive for adequacy. Let me pick three examples:

Hubert Knoblauch and Bernt Schnettler developed an approach which they call Ethnophenomenology. In their research on near-death experiences (Knoblauch and Soeffner 1999) as well as in their research on visions (Knoblauch and Schnettler

\footnotetext{
3 In the United States, the concept of phenomenological sociology had quite a different career and was prominently forwarded by Psathas (1973, 1989), among others.
} 
2001; Schnettler 2004), both researchers realized that the egological analysis of phenomenologists remains tied to their specific biographic situation:

Mundane phenomenology can only describe one's own experiences. Therefore, phenomenologists cannot make any analytic statements regarding the constitution of transcendental experiences that they themselves did not have. This explains, why the "multiple realities" of Schutz remain incomplete... The term ethnophenomenology points to the observation that philosophical laymen are quite able to reflect on their own modes of experiences. The attention of these people to the way of their extraordinary experiences is called Ethnophenomenology by us. (Schnettler 2008: 145—-transl. by T.S.E.).

The analogy to Ethnomethodology is obvious: Ethnophenomenology intends to examine the structures of actions and experiences of members of society empirically, and describes the research approach as well as its subject matter. But in contrast to Ethnomethodology, it is not methodologically produced, observable, ordinary communicative acts, but non-observable, extraordinary subjective experiences of actors that are empirically explored. Schnettler (2004) showed in his study of visionary experiences that, within the interview data, passages with ethnophenomenological descriptions of form differed clearly from the descriptions of the content of the experiences - in fact, the content of the witnessed was often of secondary importance in comparison with the extraordinary mode of the experience. Finally, he was able to elicit a number of recurring features of an Ethnophenomenology of visions of the future. Knoblauch and Schnettler carefully differentiate between the different reference levels of mundane phenomenology and Ethnophenomenology: mundane phenomenology aims at establishing a proto-sociological general theory with a universal relevance by describing general forms of human experience. Ethnophenomenology reconstructs sociologically and empirically the communicatively conveyed descriptions of extraordinary experiences (for example of near-death experiences) by everyday people in a certain historical epoch, and it transforms their generalizations into theoretical notions of a "medium range." (Schnettler 2008: 142)

Another ethnographic approach that builds closely on Schutz is the so-called lifeworld analytic ethnography of Ronald Hitzler, Anne Honer and Michaela Pfadenhauer. In the course of their research, data is collected on the one hand by participant observation, interviews in the field, analysis of artifacts and documents, and then gets hermeneutically interpreted, much like in other ethnographic approaches. On the other hand-and this is specific about this approach-the subjective experience of the researcher in the field is used explicitly and reflexively as an "instrument" of data generation and collection. The researchers thus do not only rely on participant observation for their data collection, but also on-what they call, with a different emphasis: observing participation in a field-specific role, and analyze their experiences phenomenologically. For example, a certain experience of wellbeing during a techno rave is not only researched through observation of and interviews with other participants, but also through a systematic phenomenological analysis of their own personal experiences as co-participants. The basic idea is that the genuine form of an experience is lost, once it is brought into an objectified form, 
for example by transcribing it and subsequently interpreting it hermeneutically. As a researcher, one should therefore use the immediate access to one's own subjective experience-for example, of a rave-to conduct a methodologically controlled phenomenological analysis of the experienced - that is, of the experiences and their correlates-through systematic reductions (or bracketings) (Hitzler 2005; Hitzler and Eberle 2004). In contrast to other ethnographic approaches, "the native's point of view" is not understood indirectly, but is complemented by an "existential view from the inside" (Honer 2004). This way they explore "small social life-worlds" in the sense of Benita Luckmann (1970), as raves and other events, fitness studios, and so on. As you may guess, this is quite a different approach than ethnophenomenology.

As a third approach I should mention social scientific hermeneutics as developed by Hans-Georg Soeffner (2004), a sequential hermeneutical analysis. It is well established in Germany but hardly known in other countries. Interview or interaction sequences are recorded and transcribed, and then analyzed word by word, sentence by sentence, turn by turn. The goal is to detect the hidden meaning structures in the text, the structure of the "case". In contrast to Conversation Analysis they strive for a reconstruction of meaning, not of formal structures. This kind of analysis has more and more disseminated in Germany.

If I do not present you an approach of my own, it is due to the fact that I have not developed one. Like Schutz, I am a methodologist. I am interested in the different research approaches, their epistemological and methodological foundations and their methodical procedures. And, of course, in the relevance of Alfred Schutz's life-world analysis for the methodology of the social sciences.

Let us instead open up the closing, and return to the problem of adequacy. What does it mean to conduct adequate empirical research? Are the approaches, that I briefly described, particularly evident examples of adequate empirical research? It is obviously not that easy. With his life-world analysis, Schutz explicated in detail, if unknowingly, how difficult empirical research actually is: he pointed to the manifold, interlaced interrelations of meaning, to the undistinguishable, diffuse layers of meaning and the implicit horizon of the taken for granted, to the limits of what we are able to remember and the approximate character of understanding the other, and finally to the "paradox of rationality" on the level of everyday actions. If we consider Schutz's analysis of an act of choosing in everyday life, how can we, for example, empirically grasp the petites perceptions of other actors? Even if the hermeneutic approaches try to build upon the current subjective meaning structures of everyday actors as closely as possible-complete adequacy remains an unreachable ideal to which only approximations or variants are possible. Therefore, Schutz's analysis of the life-world rather conveys a fundamental awareness of the complexity of subjective meaning constitution and social meaning construction, than an empirical instruction for adequate research. No wonder that Schutz loved analyzing literature: The thoughts, reflections and experiences of the proponents in Wilhelm Meister's apprenticeship and journeyman years (Schutz, forthcoming) or in Don Quixote and the problem of reality (Schutz 1964c) are available in detailed description. The reader gains direct access to the actors' subjective worlds by their creator's hand and is able to explore them further analytically. The hermeneutical access to the alter ego in social reality however, proves to be considerably more difficult. 
Schutz's Structures of the Life-World represent a proto-hermeneutics and reveal the basic operations of the constitution and interpretation of meaning as well as the fundamental problems of a hermeneutic approach. They do not, however, provide a practical recipe as to how to unlock the subjective meaning of social action empirically. Accordingly, the different approaches in interpretative social research start with quite diverse premises: Some only trust in interview data which then are interpreted in a sequential analysis, others only trust in audio-visual recordings of action-and interaction-sequences which are subsequently transcribed meticulously. Some reconstruct life-courses from biographical interviews, others regard them as pure narrations and solemnly examine the form of this narration or the structure of the discourse. Some intend to research the content of subjective consciousness, others confine themselves exclusively to communicative practices. Some only trust data from focus-groups, others only data of social processes in socalled "natural" situations. Some rely on interpretive interviews, others only on observations of courses of action in real-time. Although Schutz's mundane phenomenology did not bracket the ontological assumptions of the natural attitude (unlike Husserl's transcendental phenomenology), it does not provide criteria on how to assess such different types of data and how to deal with them in doing research. The various approaches of scientific research differ in terms of their ontological, epistemological and value-theoretical premises, as well as in terms of their theoretical presuppositions. And as the examples mentioned above show, they also differ from certain presuppositions of the actors in the everyday world. How empirical social research can be designed adequately, is thus not only determined by the structures of the life-world but also by additional theoretical premises: The "adequacy" of a study is judged along fairly different criteria by, for example, ethnomethodologists as opposed to the representatives of the so-called Objective Hermeneutics (Reichertz 2004).

Let me come to a conclusion: I presented a plea to resume talking about adequacy, but in a more radical fashion than is found in the formulations of the late Alfred Schutz. I argued that Schutz stripped the postulate of adequacy of its empirical requirement and made it thereby compatible with the non-empirical, partly even unrealistic models of his economist friends from the Mises-circle. I further provided some evidence that Schutz actually endorsed a more radical version of his postulate. Using adequacy as a criterion to evaluate social scientific descriptions and explanations, he introduces a different notion into qualitative research than the usual suspects, like objectivity, validity or reliability. I enjoy looking at facial expressions when I tell colleagues that their measurements are doubtlessly valid and reliable-but completely inadequate.

However, I am not a dreamer and do not expect an easy solution of all our methodological and methodical problems. Adequacy is also a kind of elusive ideal. But if it helps to explicitly refer to the phenomenological life-world analysis and to make explicit the additional theoretical and pre-theoretical premises of a sociological approach, we are on the right track. After all, it was this that Alfred Schutz was striving for: a reflective methodological analysis, and a reflexive sociology. I guess this is the goal of all of us. 


\section{References}

Becker, G. S. (1991). A treatise on the family. Cambridge MA: Harvard University Press.

Berger, P. L., \& Luckmann, T. (1966). The social construction of reality. A treatise in the sociology of knowledge. Garden City, New York: Doubleday.

Dreher, J., \& Stegmaier, P. (Eds.). (2007). Zur Unüberwindbarkeit kultureller Differenz. Grundlagentheoretische Reflexionen. Bielefeld: transcript.

Eberle, T. S. (1984). Sinnkonstitution in Alltag und Wissenschaft. Der Beitrag der Phänomenologie an die Methodologie der Sozialwissenschaften. Bern/Stuttgart: Paul Haupt.

Eberle, T.S. (1988). Die deskriptive Analyse der Ökonomie durch Alfred Schütz. In E. List, \& I. Srubar (Eds.). Alfred Schütz. Neue Beiträge zur Rezeption seines Werkes. In Studien zur Österreichischen Philosophie. Bd. XII (pp. 69-119). Amsterdam: Rodopi.

Eberle, T. S. (2000). Lebensweltanalyse und Handlungstheorie. Beiträge zur verstehenden Soziologie. Konstanz: UVK.

Eberle, T. S. (2009). In search for aprioris: Schutz's life-world analysis and Mises's praxeology. In H. Nasu, L. Embree, G. Psathas, \& I. Srubar (Eds.), Alfred Schutz and his intellectual partners (pp. 459-484). Konstanz: UVK.

Eberle, T.S., \& Srubar, I. (2010). Einleitung. In A. Schutz. Zur Methodologie der Sozialwissenschaften. Alfred Schütz Werkausgabe (ASW). Vol. IV.(pp. 9-44).

Friedmann, M. (1953). The methodology of positive economics. In essays in positive economics (pp. 3-43). Chicago: University of Chicago Press.

Garfinkel, H. (1967). Studies in Ethnomethodology. Englewood Cliffs.

Garfinkel, H. (2002). Ethnomethodology's program: Working Out durkheim's aphorism. Lanham, MD: Rowman \& Littlefield.

Garfinkel, H. (2006). Seeing sociologically: The routine grounds of social action. Lanham, MD: Rowman \& Littlefield.

Grathoff, R. (1995). Milieu und Lebenswelt. Einführung in die phänomenologische Soziologie und die sozialphänomenologische Forschung. Frankfurt/M: Suhrkamp.

Hitzler, R. (2005). Die Beschreibung der Struktur der Korrelate des Erlebens. In U. Schimank \& R. Reshoff (Eds.), Was erklärt Soziologie? (pp. 230-240). Berlin: LIT-Verlag.

Hitzler, R., \& Eberle, T. S. (2004). Phenomenological lifeworld analysis. In U. Flick, E. V. Kardorff, \& I. Steinke (Eds.), A companion to qualitative research (pp. 57-72). (B. Jenner, Trans.). Thousand Oaks, CA: Sage.

Honer, A. (2004). Life-world analysis in ethnography. In U. Flick et al., (Eds.). (2004). A companion to qualitative research (pp. 133-171). Thousand Oaks, CA: Sage.

Husserl, E. ([1936] 1970): The crisis of European sciences and transcendental phenomenology. (D. Carr, Trans.). Evanston, IL: Northwestern University Press.

James, W. (1907). Principles of psychology. New York: Holt.

Knoblauch, H., \& Soeffner, H. G. (Eds.). (1999). Todesnähe. Interdisziplinäre Beiträge zu einem außergewöhnlichen Phänomen (pp. 271-292). Konstanz: UVK.

Knoblauch, H., \& Schnettler, B. (2001). Die kulturelle Sinnprovinz der Zukunftsvision und die Ethnophänomenologie. Psychotherapie und Sozialwissenschaft: Zeitschrift für Qualitative Forschung, 3(3), 182-203.

Kries, J.v. (1889). Über die Begriffe der Wahrscheinlichkeit und Möglichkeit und ihre Bedeutung im Strafrecht. Zeitschrift für die Gesamte Strafrechtswissenschaft, 9, 528-537.

Luckmann, B. (1970). The small life-worlds of modern man. Social Research, 37, 580-597.

Luckmann, T. (1974). Preface. In A. Schutz, \& T. Luckmann. The structures of the life-world. Vol. 2. (pp.xvii-xxvi) (R. Zaner \& H Engelhardt, Trans.). Evanston, IL: Northwestern Press.

Luckmann, T. (1983). Philosophy, science, and everyday life. In Life-world and social realities (pp. 3-39). London: Heinemann.

Machlup, F. (1954). The problem of verification in economics. Southern Economic Journal, 22(6), 1-21.

Machlup, F. (1964). Paul Samuelson on theory and realism. In American economic review (Vol. LIV) (September), (pp. 733-736).

Machlup, F. (1978). Methodology of economics and other social sciences. New York: Academic Press.

Mises, L. V. (1940). Nationalökonomie. Theorie des Handelns und Wirtschaftens. Geneva: Editions Union Genf.

Mises, L. V. (1949). Human action: A treatise on economics. New Haven, CT: Yale University Press. 
Prendergast, C. (1986). Alfred Schütz and the Austrian school of economics. In American Journal of Sociology, 92(1), 1-26.

Psathas, G. (1973). Phenomenological sociology. New York: Wiley.

Psathas, G. (1989). Phenomenology and sociology: Theory and research. University Press of America.

Raab, J., Pfadenhauer, M., Stegmaier, P., Dreher, J., \& Schnettler, B. (Eds.). (2008). Phänomenologie und Soziologie. Theoretische Positionen, aktuelle Problemfelder und empirische Umsetzungen. Wiesbaden: VS Verlag für Sozialwissenschaften.

Reichertz, J. (2004). Objective hermeneutics and hermeneutic sociology of knowledge. In U. Flick, E. von Kardorff, \& I. Steinke (Eds.), A companion to qualitative research (pp. 290-295). Thousand Oaks, CA: Sage.

Schnettler, B. (2004). Zukunftsvisionen: Transzendenzerfahrung und Alltagswelt. Konstanz: UVK.

Schnettler, B. (2008). Soziologie als erfahrungswissenschaft: Überlegungen zum verhältnis von mundanphänomenologie und ethnophänomenologie. In J. Raab, M. Pfadenhauer, P. Stegmaier, J. Dreher, \& B. Schnettler (Eds.), Phänomenologie und soziologie: Theoretische positionen, aktuelle problemfelder und empirische umsetzungen (pp. 141-149). Wiesbaden: VS Verlag für Sozialwissenschaften.

Schutz, A. (1955a). Letter to Adolph Lowe from October 17th (unpublished correspondence from the Sozialwissenschaftliches Archiv der Universität Konstanz).

Schutz, A. (1955b). Letter to Adolph Lowe from December 7th (unpublished correspondence from the Sozialwissenschaftliches Archiv der Universität Konstanz).

Schutz, A. (1962a). Collected papers Vol. I: The problem of social reality. The Hague: Martinus Nijhoff.

Schutz, A. (1962b). Common-sense and scientific interpretation of human action. In Collected papers Vol. I: The problem of social reality (pp. 3-47). The Hague: Martinus Nijhoff.

Schutz, A. (1962c). Concept and theory formation in the social sciences. In Collected Papers Vol. I: The problem of social reality (pp. 48-66). The Hague: Martinus Nijhoff.

Schutz, A. (1962d). Choosing among projects of action. In Collected Papers Vol. I: The problem of social reality (pp. 67-98). The Hague: Martinus Nijhoff.

Schutz, A. (1964a). The social world and the theory of social action. In Collected papers Vol. II: Studies in social theory (pp. 3-19). The Hague: Martinus Nijhoff.

Schutz, A. (1964b). The problem of rationality in the social world. In Collected papers Vol. II: Studies in social theory (pp. 64-88). The Hague: Martinus Nijhoff.

Schutz, A. (1964c). Don Quixote and the problem of reality. In Collected papers Vol. II: Studies in social theory (pp. 135-158). The Hague: Martinus Nijhoff.

Schutz, A. (1967). The phenomenology of the social world. Evanston, IL: Northwestern University Press.

Schutz, A. (1972). Choice and the social sciences. In L. E. Embree (Ed.), Life-world and consciousness: Essays for Aron Gurwitsch (pp. 565-590). Evanston, IL: Northwestern University Press.

Schutz, A. (2007). Sinn und Zeit. Frühe Wiener Arbeiten und Entwürfe. Alfred Schütz Werkausgabe (ASW) Vol. I. Konstanz: UVK.

Schutz, A. (2010). Zur Methodologie der Sozialwissenschaften. Alfred Schütz Werkausgabe (ASW) Vol. IV. Konstanz: UVK.

Schutz, A. (forthcoming). Wilhelm Meisters Lehrjahre [1948-II-1]; Zu Wilhelm Meisters Wanderjahren [1948-II-2]. In Schriften zur Literatur. Alfred Schutz Werkausgabe (ASW) Vol. VIII. Konstanz: UVK.

Schutz, A., \& Luckmann, T. (1973). The structures of the life-world Vol. 1. (R. Zaner, \& H. T. Engelhardt Jr, Trans.). Evanston, IL: Northwestern University Press.

Schutz, A., \& Luckmann, T. (1989). The structures of the life-world Vol. II. (R. Zaner, \& D. J. Parent, Trans.). Evanston, IL: Northwestern University Press.

Soeffner, H. -G. (2004). Social-scientific hermeneutics. In U. Flick, E. von Kardorff, \& I. Steinke (Eds.), A Companion to qualitative research (pp. 95-100). Thousand Oaks, CA: Sage.

Weber, M. ([1922]1978). Economy and society: An outline of interpretive sociology. G. Roth, \& C. Wittich, (Eds.). Berkley: University of California Press.

Weber, M. (1949). The methodology of the social sciences. (E. Shils, \& H. Finch, Trans.). New York, NY: The Free Press.

Weber, M. (1994). Sociological writings. (W. Heydebrand, Ed.). London: Continuum. 